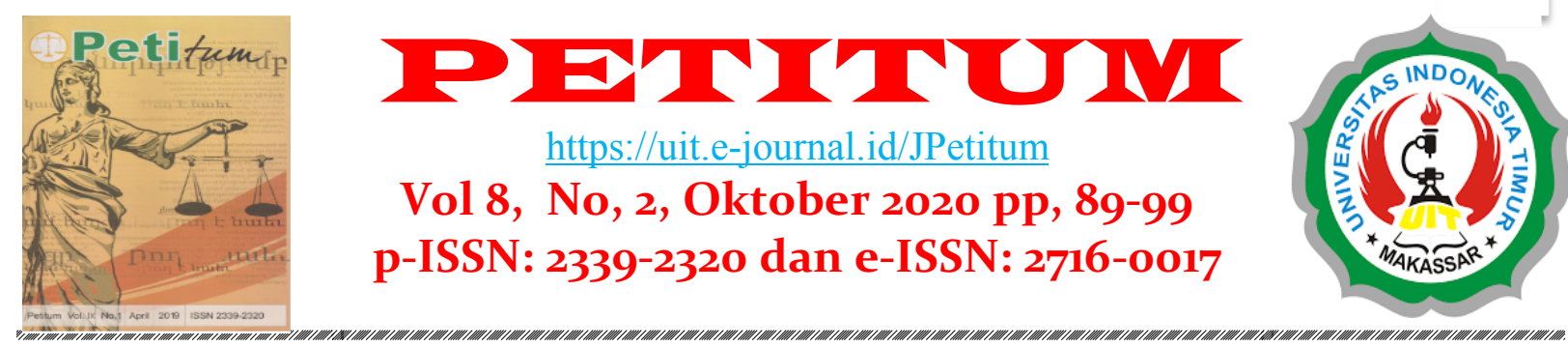

\title{
Peralihan Kredit kepemilikan Rumah Subsidi Tanpa Persetujuan Pihak Bank
}

Diman Ade Mulada $_{1}$, Arief Rahman ${ }_{2}$

${ }_{1}$ Fakultas Hukum, Universitas Mataram, Email: ademulada@gmail.com

2 Fakultas Hukum, Universitas Mataram, Email: ariefrahmanburaeng@gmail.com

\begin{abstract}
Artikel info
Artikel history:

Submission: 21-09-2020

Received; 22-09-2020

Revised: 17-10-2020

Published: 17-10-2020

Keywords:

Credit transfer; subsidized housing;

ABSTRACT The purpose of this study was to analyze the strength of the deed of subsidized housing ownership credit without the approval of the bank. The type of research is using normative legal research with statutory and conceptual approaches to the method. The results of the research conducted concluded that the power of the subsidized mortgage loan transfer deed made by the subsidized mortgage debtor to a third party (buyer) without the approval of the bank, only binds the subsidized mortgage debtor with a third party (buyer). Meanwhile, the bank is not bound by the transfer. So that the consequence is that the bank does not recognize the transfer of subsidized housing loans made by subsidized mortgage debtors to third parties, and does not eliminate the obligation of subsidized mortgage debtors to pay off their debts to the bank until the agreed period of time, even though the next payment is up to the credit period. ends done by a third party (buyer).
\end{abstract}

Bank

\section{Kata Kunci:}

Peralihan kredit;

Rumah subsidi; Bank

\begin{abstract}
ABSTRAK: Tujuan penelitian ini adalah untuk menganalisis kekuatan akta peralihan kredit kepemilikan rumah subsidi tanpa persetujuan pihak bank. Adapun jenis penelitiannya adalah menggunakan penelitian hukum normatif dengan metode pendekatan peraturan perundang-undangan dan konseptual. Hasil penelitian yang dilakukan menyimpulkan bahwa Kekuatan akta peralihan kredit kepemilikan rumah subsidi yang dibuat oleh debitur KPR subsidi kepada pihak ketiga (pembeli) tanpa persetujuan dari pihak bank, hanya mengikat pihak debitur KPR subsidi dengan pihak ketiga (pembeli). Sedangkan bagi pihak bank tidak terikat terkait dengan peralihan tersebut. Sehingga konsekuensinya bank tidak mengakui terjadinya peralihan kredit kepemilikan rumah subsidi yang dibuat oleh debitur KPR subsidi kepada pihak ketiga, dan tidak menghapuskan kewajiban debitur KPR subsidi untuk melunasi hutangnya kepada pihak bank sampai dengan jangka waktu yang telah disepakti, meskipun pembayaran berikutnya sampai dengan jangka waktu kredit berakhir dilakukan oleh pihak ketiga (pembeli).
\end{abstract}




\section{PENDAHULAN}

Sebagai negara berkembang Indonesia mengalami berbagai masalah terutama dalam pemenuhan kebutuhan hidup baik berupa sandang, pangan dan papan. Dalam hal pemenuhan kebutuhan hidup berupa papan, tidak seluruhnya dapat dipenuhi oleh masyarakat maupun pemerintah karena jumlahnya yang terbatas. Salah satu bentuk kebutuhan hidup manusia berupa papan yaitu rumah. Berdasarkan Pasal 1 ayat (1) Undang-Undang Nomor 4 Tahun 1992 tentang Perumahan dan Pemukiman, ditentukan bahwa yang dimaksud dengan rumah adalah bangunan yang berfungsi sebagai tempat tinggal dan hunian bagi pembinaan keluarga.

Rumah merupakan kebutuhan dasar dan mempunyai fungsi yang sangat penting bagi kehidupan manusia. Namun karena perkembangan ekonomi yang tidak seimbang dengan perkembangan penduduk yang begitu pesat berdampak pada sulitnya individu untuk memiliki rumah. Tingginya kebutuhan terhadap rumah mengakibatkan semakin tingginya harga tanah. Harga tanah yang tinggi menyebabkan semakin sulitnya masyarakat untuk memiliki rumah yang layak di tempat yang mereka inginkan khususnya bagi masyarakat berpenghasilan rendah. Hal ini membuat seseorang memilih untuk memiliki rumah di suatu kompleks perumahan sehingga mereka tidak perlu mencari lahan untuk mendirikan rumah. Kepemilikan rumah di perumahan dapat diperoleh dengan dua cara yaitu:

1. Cash

Yaitu konsumen dalam melakukan pembelian rumah, pembayarannya dilakukan secara tunai.

2. Kredit.

Yaitu uang bank yang dipinjamkan kepada nasabah dan akan dikembalikan pada suatu waktu tertentu di masa mendatang disertai dengan suatu kontra prestasi berupa bunga (Sinungan, 2000). Dalam hal ini Konsumen dalam melakukan pembelian rumah, pembayarannya dilakukan secara bertahap dengan jangka waktu yang telah disepakati antara konsumen dengan pihak Bank.

Dengan demikian bagi masyarakat yang berpenghasilan rendah jika kesulitan untuk memiliki rumah secara tunai, maka dapat dilakukan dengan cara kredit, dimana dalam hal ini pemerintah telah menyediakan suatu program untuk memudahkan masyarakat dalam memenuhi kebutuhan akan rumah yaitu dengan adanya program Kredit Pemilikan Rumah (KPR) (Rahardjo, 2010). Kredit Pemilikan Rumah (KPR) adalah fasilitas yang diberikan untuk membeli rumah dengan kredit kepada bank. KPR dipandang menguntungkan karena dapat membantu memiliki rumah sendiri, walaupun tidak cara pembelian tunai. Prinsip KPR adalah membiayai terlebih dahulu biaya pembelian atau pembangunan rumah, kemudian dana untuk membayarkan balik dilakukan dengan cara dicicil (Badrulzaman, 2014).

Di Indonesia terdapat dua jenis Kredit Pemilikan Rumah yaitu: Kredit Pemilikan Rumah Subsidi dan Non Subsidi. Kredit Pemilikan Rumah Subsidi merupaakan Kredit atau pembiayaan pemilikan rumah yang mendapat bantuan dan/atau kemudahan perolehan rumah dari pemerintah berupa dana murah jangka panjang dan subsidi perolehan rumah yang diterbitkan oleh Bank Pelaksana baik secara konvensional maupun dengan prinsip syariah (http://pembiayaan.pu.go.id). Sedangkan Kredit 


\section{1 | PETITUM, Vol. 8, No.2, Oktober 2020}

Pemilikan Rumah Non Subsidi adalah Kredit atau pembiayaan pemilikan rumah yang tidak mendapat bantuan dan/atau kemudahan perolehan rumah dari pemerintah yang dilakukan oleh bank baik secara konvensional maupun dengan prinsip syariah.Untuk Program Kredit Pemilikan Rumah subsidi dilaksanakan oleh Bank Pelaksana. Bank Pelaksana adalah bank umum, bank umum syariah, dan unit syariah yang bekerjasama dengan Kementerian Pekerjaan Umum dan Perumahan Rakyat dalam rangka penyaluran kemudahan dan/atau bantuan perolehan rumah bagi masyarakat berpenghasilan rendah (http://pembiayaan.pu.go.id).

Dengan adanya kredit pemilikan rumah subsidi ini membantu mengatasi permasalahan terhadap kebutuhan akan rumah khususnya bagi masyarakat yang memiliki penghasilan rendah (Mangeswuri, 2016). Berdasarkan Peraturan Menteri Pekerjaan Umum Dan Perumahan Rakyat Republik Indonesia Nomor: 21/ PRT /M / 2016 Tentang Kemudahan Dan /Atau Bantuan Perolehan Rumah Bagi Masayarakat Berpenghasilan Rendah menyebutkan bahwa Rumah Sejahtera (subsidi) Tapak yang perolehannya melalui KPR Sejahtera (subsidi) tidak boleh diperjual-belikan atau dipindahtangankan dengan bentuk perbuatan hukum apapun, kecuali:

a. Pewarisan;

b. telah dihuni lebih dari 5 (lima) tahun untuk Rumah Sejahtera Tapak;

c. pindah tempat tinggal akibat peningkatan sosial ekonomi; atau

d. untuk kepentingan Bank Pelaksana dalam rangka penyelesaian kredit atau pembiayaan bermasalah.

Namun dalam prakteknya ternyata terdapat beberapa nasabah kredit rumah subsidi yang mengalihkan rumah yang menjadi objek KPR tersebut sebelum jangka waktu 5 tahun kepada pihak lain (pembeli) tanpa persetujuan pihak bank. Proses peralihan tersebut dilakukan dengan menggunakan akta yang dibuat dihadapan notaris. Berdasarkan uraian latar belakang diatas, maka permasalahan yang diangkat dalam artikel ini adalah bagaimana kekuatan akta peralihan kredit kepemilikan rumah subsidi tanpa persetujuanpihak bank?

\section{METODE PENELITIAN}

Bertolak dari judul dan perumusan permasalahan di atas, maka jenis penelitian ini adalah penelitian hukum normatif. Penelitian hukum normatif dikonsepkan sebagai apa yang tertulis dalam peraturan perundang-undangan (law in books) atau hukum yang dikonsepkan sebagai kaidah atau norma yang merupakan patokan berprilaku manusia yang dianggap pantas (Amiruddin \& Asikin, 2018). Metode pendekatan yang digunakan yaitu pendekatan perundang-undangan dan konseptual. Metode tersebut mengkaji hukum tidak sebatas sebagai seperangkat aturan semata, melainkan juga mengkaji interaksi norma-norma terkait dengan masyarakat. Penelitian ini melibatkan bahan hukum primer dan sekunder yaitu berupa peraturan perundang-undnagan yang terkait dengan objek penelitian dan dokumen lainnya seperti buku, artikel dan lain sebagainya. 


\section{HASIL DAN PEMBAHASAN}

\section{Peralihan Kredit kepemilikan Rumah Subsidi Tanpa Persetujuan Pihak Bank}

Berawal dari amanah Undang-Undang Dasar 1945 pasal 28 H ayat (1) bahwa "Setiap orang berhak hidup sejahtera lahir dan batin, bertempat tinggal dan mendapatkan lingkungan hidup yang baik dan sehat...", kemudian amanah tersebut diemban oleh UU No 1 tahun 2011 tentang Perumahan dan Kawasan Permukiman dan UU No 20 Tahun 2011 tentang Rumah Susun yang memperjelas bahwa negara bertanggung jawab untuk memenuhi kebutuhan rumah bagi setiap orang terutama masyarakat berpenghasilan rendah (MBR). Namun dalam perjalanannya, berdasarkan data BPS tahun 2010 masih terdapat backlog kebutuhan rumah sebesar 13,5 juta unit rumah (https://ppdpp.id/profil-p2dpp/). Untuk itu dalam kedua UU tersebut telah pula diamanatkan bahwa pemerintah atau pemerintah daerah dapat memenuhi kebutuhan rumah tersebut melalui pemberian bantuan dan kemudahan.

Sebagai pelaksanaan dari kedua Undang-Undang tersebut,maka pemerintah kemudian meluncurkan program bantuan dan kemudahan berupa Subsidi Kredit Pemilikan Rumah (KPR) dengan menggunakan skema Fasilitas Likuiditas Pembiayaan Perumahan (FLPP) yang kemudian populer dengan istilah KPR FLPP atau KPR Subsidi. Pemberian Kredit Pemilikan Rumah (KPR) subsidi diperuntukkan bagi masyarakat berpenghasilan rendah (MBR) dengan syarat:

1. Memiliki penghasilan tetap maupun tidak tetap paling banyak Rp. 4.ooo.ooo,oo (empat juta rupiah) per bulan.

2. Tidak memiliki rumah yang dibuktikan dengan surat keterangan dari Kepala Desa/Lurah setempat/Instansi tempat bekerja;

3. Belum pernah menerima subsidi Pemerintah untuk pemilikan rumah;

4. Memiliki Nomor Pokok Wajib Pajak (NPWP); dan

5. Menyerahkan fotokopi (SPT) Tahunan PPh Orang Pribadi atau surat pernyataan bahwa penghasilan yang bersangkutan tidak melebihi batas penghasilan yang dipersyaratkan.

Masyarakat yang memenuhi syarat sebagaimana yang disebutkan diatas, kemudian dapat mengajukan permohonan KPR subsidi ke bank pelaksana dengan melampirkan persyaratan-persyaratan yang sudah ditentukan. Bank pelaksana kemudian melakukan verifikasi terhadap permohonan KPR subsidi yang diajukan, yang meliputi:

a. pengecekan administrasi terhadap dokumen persyaratan;

b. analisa kelayakan dan kemampuan mengangsur pemohon KPR subsidi; dan;

c. pengecekan fisik bangunan rumah, prasarana dan sarana, serta utilitas umum (PSU).Fisik bangunan rumah dan PSU ketika dilakukan pengecekan harus telah siap dihuni, berfungsi dan sekurang-kurangnya harus dilengkapi dengan:

1) atap, lantai dan dinding yang memenuhi persyaratan teknis keselamatan, keamanan dan kehandalan bangunan;

2) terdapat jaringan distribusi air bersih perpipaan dari PDAM atau sumber air bersih lainnya;

3) utilitas jaringan listrik yang berfungsi;

4) jalan lingkungan yang telah selesai dan berfungsi; dan 
5) saluran/drainase lingkungan yang telah selesai dan berfungsi.

Setelah verefikasi dilakukan, kemudian dilanjutkan dengan proses penandatanganan perjanjian kredit atau akadKPR Subsidi dengan pemohon kredit rumah subsidi yang telah disetujuipermohonan kreditnya oleh Bank Pelaksana. Perjanjian kredit atau akad adalah perjanjian antara bank sebagai kreditor dengan nasabah debitor mengenai penyediaan uang atau tagihan yang dapat dipersamakan dengan itu yang mewajibkan nasabah-nasabah debitor untuk melunasi hutangnya setelah jangka waktu tertentu dengan jumlah bunga, imbalan, atau pembagian hasil keuntungan (Sjahdeini, 2009).

Perjanjian kredit atau akad KPR subsidi wajib mencantumkan secara tertulis bahwa KPR subsidi didukung dana FLPP. Pemohon kredit yang telah menandatangani Perjanjian Kredit dan/atau Akad KPR subsidi,selanjutnya disebut sebagai debitur atau nasabah dan berhak menerima kunci rumah sebagai realisasi dari perjanjian kredit rumah subsidi (Yusuf \& Maryanto, 2018).

Dengan telah ditandangani perjanjian kredit oleh debitur KPR subsidi, makasejak saat itu hak dan kewajiban melekat padanya. Berikut beberapa kewajiban yang melekat pada debitur KPR subsidi, berkaitan dengan pembelian Rumah subsidi:

1. Membayar angsuran KPR subsidi secara tertib dan tepat waktu hingga jangka waktu kredit selesai/lunas;

2. Menggunakan sendiri dan menghuni rumah subsidi sebagai tempat tinggal dalam jangka waktu paling lambat 1 (satu) tahun setelah serah terima rumah.;

3. Memelihara rumah subsidi dengan baik;

4. Mengembalikan bantuan FLPP kepada Pusat Pengelola Dana Dan Pembiayaan Perumahan (PPDPP) Kementerian Pekerjaan Umum \& Perumahan Rakyat, apabila melakukan pelanggaran terhadap ketentuan KPR subsidi.

5. Rumah subsidi tidak boleh disewakan dan atau dialihkan, kecuali:

a. Pewarisan;

Yaitu apabila debitur KPR subsidi meninggal dunia, maka secara hukum beralih kepada ahli waris yang sah.

b. Telah dihuni lebih dari 5 (lima) tahun;

Yaitu bahwa proses kredit rumah subsidi tersebut sudah berjalan minimal 5 (lima) tahun dan telah dihuni oleh debitur KPR subsidi.

c. Pindah tempat tinggal akibat peningkatan sosial ekonomi;

Yaitu Pindah tempat tinggal dibuktikan dengan:

1) surat keterangan pindah dari pihak yang berwenang di lokasi rumah sejahtera tapak atau satuan rumah sejahtera susun berada; dan

2) surat pernyataan bahwa yang bersangkutan telah atau akan memiliki rumah lain.

d. Untuk kepentingan Bank Pelaksana dalam rangka penyelesaian kredit atau pembiayaan bermasalah.

Yaitu berkaitan apabila debitur KPR subsidi wanprestasi atau tidak melaksanakan kewajiban pembayarannya, maka dilakukan eksekusi terhadap objek jaminan rumah subsidi tersebut.

Namun dalam prakteknya ternyata terdapat beberapa debitur KPR subsidi yang melakukan pengalihan hak kredit rumah subsidinya kepada pihak ketiga (pembeli). 
Pengalihan hak kredit yang dimaksud dalam hal ini adalah pengalihan kewajiban yang berupa pembayaran angsuran kredit perumahan, tindakan ini adalah merupakan suatu delegasi yaitu pengalihan kewajiban/perhantian debitor, ketika telah adanya piutang dan merupakan tindakan sepihak yaitu tindakan debitor (Fuady, 2002). Pengalihan kewajiban didalam kitab Undang-Undang Hukum Perdata dikenal dengan istilah Novasi, begitu juga bila dilihat dari aspek hukum perikatan, proses alih debitur yang dilakukan dalam penyaluran Kredit Perumahan (KPR) merupakan perbuatan hukum novasi (Kaffa, 2020). Novasi adalah suatu proses pergantian perjanjian lama oleh suatu perjanjian baru, yang menyebabkan perjanjian lama hapus, sehingga yang berlaku selanjutnya adalah perjanjian baru dengan perubahan terhadap syarat dan kondisinya, dan atau dengan perubahan terhadap para pihak dalam perjanjian tersebut (Fuady, 2003).

Proses pengalihan hak kredit kepemilikan rumah subsidi kepada pihak ketiga (pembeli) harus memperoleh izin dari pihak bank sebagai kreditor, karena novasi baru terjadi, kalau kreditor telah menerima atau menyetujui person debitor yang baru, dan dengan tegas menyatakan bahwa ia membebaskan debitor lama, dari kreditornya berdasarkan perikatan yang lama dan kewajibannya berprestasi (lebih lanjut) terhadap kreditor (Kusumawati, 2018). Dengan perkataan lain, dengan hanya menerima penawaran seorang debitor baru saja yang disodorkan debitor lama belum terjadi Novasi, itulah sebabnya bahwa undang-undang mensyaratkan bahwa Novasi di sana baru terjadi, kalau kreditor sudah menerima penawaran person debitor baru, menyatakan secara tegas bahwa ia membebaskan debitor lama.

Namun dalam prakteknya dilapangan ternyata proses peralihan kredit kepemilikan rumah oleh debitur KPR subsidi kepada pihak ketiga (pembeli) dilakukan tanpa persetujuan dari pihak bank sebagai kreditor. Penyebab debitur KPR subsidi mengalihkan kredit kepemilikan rumah subsidinya kepada pihakketiga (pembeli) tanpa persetujuan bank, dikarenakan debitur KPR subsidimembutuhkan uang atau mengalami kesulitan ekonomi sehingga tidak lagi mampu melanjutkan angsuran KPR subsidi, namun karena:

1. Jangka waktu kredit rumah subsidinya belum mencapai 5 (lima) tahun.

2. Proses alih debitur dengan persetujuan pihak bank memakan waktu yang lama, karena sama saja dengan membuat perjanjian jual beli yang baru. Dimana bank memulai dari awal lagi dan biaya yang dikeluarkan juga sama dengan perjanjian yang baru (Putrisani, 2019).

3. Ketidakpahaman para pihak akan hukum, khususnya tentang proses alih debitur.

Maka kemudian debitur KPR subsidi mengalihkan kredit kepemilikan rumah subsidinya kepada pihak ketiga (pembeli) tanpa persetujuan bank. Didalam Peraturan Menteri Pekerjaan Umum Dan Perumahan Rakyat Republik Indonesia Nomor: 21/ PRT /M /2016 Tentang Kemudahan Dan /Atau Bantuan Perolehan Rumah Bagi Masayarakat Berpenghasilan Rendah sebenarnya sudah diatur mengenai proses peralihan kredit kepemilikan rumah subsidi kepada pihak ketiga. Hal ini dapat dilihat dalam ketentuan pasal 52 ayat (5) yang menyatakan bahwa pengalihan kepemilikan rumah subsidi hanya dapat dilakukan kepada Masyarakat berpenghasilan rendah (MBR) berdasarkan peraturan perundang-undangan yang berlaku. Dengan demikian maka proses peralihan terhadap rumah subsidi yang masih dalam proses kredit dilakukan 
berdasarkan ketentuan yang mengatur mengenai peralihan kewajiban yang dalam KUHPerdata dikenal dengan istilah novasi. Ketentuan mengenai novasi diatur dalam Pasal 1413 sampai dengan Pasal 1424 Kitab Undang-Undang Hukum Perdata (KUHPerdata). Adapun beberapa model novasi yang sebagaimana yang disebutkan dalam pasal 1413 KUHPerdata, yaitu:

1. Novasi objektif;

Yaitu pembaruan hutang dengan mana debitur membuat suatu kontrak hutang yang baru untuk menggantikan hutangnya yang lama. Jadi, dalam hal ini yang diganti dengan kontrak baru semata-mata adalah hutangnya dan tidak ada perubahan pihak debitur ataupun kreditur.

2. Novasi subjektif pasif;

Yaitu adanya pergantian debitur lama dengan debitur baru, dan kreditur setuju bahwa debitur lama dibebaskan dari kewajibannya. Akibatnya, antara debitur lama dengan kreditur tidak lagi mempunyai kontrak utang piutang.

3. Novasi subjektif aktif

Yaitu adanya pergantian kreditur lama dengan kreditur baru. Akibatnya, antara debitur dengan kreditur lama tidak lagi mempunyai kontrak hutang piutang.

Dari ketiga jenis novasi yang disebutkan diatas, maka peralihan kredit kepemilikan rumah subsidi yang dilakukan oleh debitur KPR subsidi kepada pihak ketiga (Pembeli) termasuk dalam jenis novasi subjektif pasif. Namun yang menjadi persoalannya adalah dalam prakteknya, peralihan rumah subsidi dari debitur KPR subsidi kepada pihak ketiga (pembeli) tidak meminta persetujuan dari pihak bank sebagai kreditur, sehingga tidak memenuhi unsur untuk dapat dikatakan sebagai novasi subyektif pasif.

Peralihan kredit kepemilikan rumah subsidi yang dilakukan oleh debitur KPR subsidi kepada pihak ketiga (pembeli), dalam prakteknya, peneliti melihat rata-rata dilakukan sebelum jangka waktu 5 (lima) tahun yang dibuat dalam bentuk akta dihadapan notaris. Adapun beberapa jenis akta yang dibuat oleh notaris terkait dengan peralihan kredit kepemilikan rumah subsidi, yaitu:

a. Akta perikatan jual beli;

Yaitu suatu perjanjian yang dibuat oleh penjual dan pembeli rumah subsidi sebagai pengikatan awal sebelum para pihak membuat Akta Jual Beli (AJB) di hadapan Pejabat Pembuat Akta Tanah (PPAT).

Akta Pengikatan Jual Beli dibuat dengan 2 (dua) versi, yaitu:

1) Akta Pengikatan jual beli yang baru merupakan janji-janji karena biasanya harganya belum lunas (biasa disebut sebagai: PJB Belum Lunas);

2) Akta Pengikatan Jual beli yang pembayarannya sudah dilakukan secara lunas, namun belum bisa dilaksanakan pembuatan akta jual belinya di hadapan PPAT yang berwenang, karena masih ada proses yang belum selesai.

Dari 2 (dua) versi akta pengikatan jual beli diatas, maka untuk peralihan kredit kepemilikan rumah subsidi yang dilakukan oleh debitur kepada pihak ketiga (debitur baru), menggunakan akta pengikatan jual beli yang pembayarannya sudah dilakukan 
secara lunas kepada debitur, namun belum bisa dibuatkan akta jual beli, karena masih ada proses yang belum selesai yaitu:

1. Rumah subsidi tersebut masih dalam proses kredit dibank;

2. Proses kredit rumah subsidi tersebut belum berjalan sampai 5 (lima) tahun, sebagaimana batas yang ditentukan didalam Peraturan Menteri Pekerjaan Umum Dan Perumahan Rakyat Republik Indonesia Nomor: 21/ PRT /M / 2016, sehingga belum bisa dialihkan.

a. Akta pemberian kuasa

Yaitu suatu perjanjian dengan mana seorang memberikan kekuasaan kepada orang lain yang menerimanya untuk atas namanya, menyelengarakan suatu urusan tertentu.

Dalam peralihan kredit kepemilikan rumah subsidi, pembuatan akta pemberian kuasa dibuat dalam 2 (dua) bentuk, yaitu:

b. Akta kuasa menjual;

Yaitu kuasa yang digunakan untuk memindahtangankan benda yang sejatinya hanya dapat dilakukan oleh pemiliknya saja. Dengan adanya akta kuasa menjual maka pada saat terpenuhinya semua persyaratan untuk meningkatkan Perikatan Jual Beli menjadi Akta Jual Beli, penjual tidak perlu repot-repot untuk hadir kembali menandatangani Akta Jual Beli-nya, cukup pembeli saja. Pembeli bertindak selaku kuasa dari penjual, atas dasar kuasa yang sudah ada di Perikatan Jual Beli, yang mana Perikatan Jual Beli itu telah ditandatangani dengan sempurna oleh penjual dan pembeli.

Kuasa Menjual dalam peralihan kredit kepemilikan rumah subsidi bersifat mutlak, artinya tidak dapat dicabut kembali dan tidak akan berakhir karena sebab-sebab yang diatur dalam Pasal 1813 KUHPerdata. Hal ini untuk menjamin kepastian hukum bagi pembeli yang sudah membayar lunas harga yang sudah dibayarkannya secara penuh namun belum bisa dilaksanakan baliknamanya karena satu dan lain hal ada syarat-syarat yang belum terpenuhi.

c. Akta kuasa mengambil sertifikat.

Yaitu kuasa yang digunakan oleh pembeli rumah subsidi untuk mengambil sertifikat rumah subsidi yang dibelinya pada lembaga bank dimana rumah tersebut diagunkan sebagai jaminan utang.

Akta Pengikatan Jual Beli (APJB), Akta kuasa menjual, Akta kuasa mengambil sertifikat yang dibuat dihadapan notaris merupakan akta autentik.Akta autentik adalah akta yang dibuat dan diresmikan dalam bentuk hukum, oleh atau dihadapan pejabat umum, yang berwenang untuk berbuat sedemikian itu, ditempat dimana akta itu dibuat (Soegondo, 1991). Menurut Pasal 1870 Kitab UndangUndang Hukum Perdata, "suatu akta autentik memberikan kepada para pihak yang membuatnya suatu bukti yang sempurna tentang apa yang dimuat didalamnya”.

Dengan demikian maka menurut peneliti bahwa kekuatan aktaperalihan kredit kepemilikan rumah subsidi dalam bentuk akta pengikatan jual beli (APJB), yang dibuat oleh debitur KPR subsidi kepada pihak ketiga (pembeli) tanpa persetujuan 


\section{7 | PETITUM, Vol. 8, No.2, Oktober 2020}

pihak bank, hanya mengikat debitur KPR subsidi dengan pihak ketiga (pembeli), sedangkan bagi pihak bank tidak terikat terkait dengan peralihan tersebut.Sehingga konsekuensinya bank tidak mengakui terjadinya peralihan kredit kepemilikan rumah subsidi yang dibuat oleh debitur KPR subsidi kepada pihak ketiga (pembeli), dan tidak menghapuskan kewajiban debitur KPR subsidi untuk melunasi hutangnya kepada pihak Bank sampai dengan jangka waktu yang telah disepakti. Artinya disini yang namanya tertera dalam hubungan hukum dengan bank adalah tetap debitur KPR subsidi, meskipun pembayarannya selanjutnya sampai dengan jangka waktu kredit berakhir dilakukan oleh pihak ketiga (pembeli).

Pihak bank sebagai pemegang jaminan rumah subsidi yang dilakukan peralihan, apabila mengetahui hal tersebut dan memiliki bukti, maka secara hukum dapat mengajukan permohonan pembatalan melalui Peradilan umum atas penjualan tersebut, sehingga penjualan tersebut menjadi tidak sah serta meminta mengembalikan dana kemudahan dan/atau bantuan pembiayaan perumahan (subsidi) yang telah diperoleh melalui Bank. Namun dalam kenyataannya hal ini hampir tidak dilakukan oleh pihak bank, karena peralihan kredit kepemilikan rumah subsidi oleh debitur KPR subsidi kepada pihak ketiga (pembeli) dilakukan secara diam-diam dengan menggunakan akta autentik dan bank tidak mengetahui hal tersebut, karena pembayaran rumah subsidi tersebut tetap berjalan lancar sesuai dengan batas waktu yang ditentukan dan tetap atas nama debitur lama.

Menurut pendapat peneliti bahwa peralihan kredit rumah subsidi yang dilakukan oleh debitur kepada pihak ketiga tanpa persetujuan bank sebenarnya merugikan pihak debitur itu sendiri karena nama dalam perjanjian kredit dengan pihak bank tetap masih menggunakan nama debitur lama sehingga kalau dia mau mengajukan permohonan kredit lagi mungkin agak sulit dan kalau terjadi kredit macet dalam kaitannya dengan pembayaran rumah subsidi maka yang terkena sanksi atau blacklist adalah debitur lama tersebut, sehingga konsekuensinya tidak ada lagi lembaga pembiayaan yang bersedia memberikan kredit kepadanya. Sedangkan bagi pihak ketiga (pembeli) kerugiannya adalah tidak dapat langsung melakukan proses balik nama terhadap kepemilikan rumah subsidi tersebutkarena masih dalam proses kredit atas nama debitur lama serta belum memenuhi syarat untuk dilakukan proses peralihan sebagimana yang diatur dalam Peraturan Menteri Pekerjaan Umum Dan Perumahan Rakyat Republik Indonesia Nomor: 21/ PRT /M / 2016 terkait dengan syarat-syarat untuk bisa dilakukan peralihan kepemilikan terhadap rumah subsidi, sehingga belum bisa dibuatkan akta jual beli sebagai dasar dilakukan proses balik nama. Namun untuk membuktikan bahwa telah terjadi kesepakatan peralihan kredit kepemilikan rumah subsidi maka dibuatkan akta perikatan jual beli (APJB), serta untuk memudahkan pembeli rumah subsidi mengambil sertifikat atas nama debitur lama dan melakukan proses balik nama ketika rumah tersebut telah lunas pembayaran kreditnya maka dibuatkan akta kuasa pengambilan sertifikat dan akta kuasa menjual..

\section{KESIMPULAN}

Kekuatan akta peralihan kredit kepemilikan rumah subsidi yang dibuat oleh debitur KPR subsidi kepada pihak ketiga (pembeli) tanpa persetujuan dari pihak bank, hanyamengikatpihak debitur KPR subsidi dengan pihak ketiga (pembeli). Sedangkan 
bagi pihak bank tidak terikat terkait dengan peralihan tersebut. Sehingga konsekuensinya bank tidak mengakui terjadinya peralihan kredit kepemilikan rumah subsidi yang dibuat oleh debitur KPR subsidi kepada pihak ketiga, dan tidak menghapuskan kewajiban debitur KPR subsidi untuk melunasi hutangnya kepada pihak bank sampai dengan jangka waktu yang telah disepakti, meskipun pembayaran berikutnya sampai dengan jangka waktu kredit berakhir dilakukan oleh pihak ketiga (pembeli).

\section{SARAN}

Sebaiknya pihak debitur yang ingin mengalihkan rumah subsidinya sebelum jangka waktu yang ditentukan tanpa persetujuan pihak bank agar mengurungkan niatnya tersebut, karena merugikan pihak debitur itu sendiri, dimana nama yang tertera dalam kredit rumah subsidi tersebut tetap atas nama debitur itu sendiri sehingga nanti apabila dikemudian hari dia ingin mengajukan permohonan kredit lagi tentunya akan mengalami kendala dan apabila pihak ketiga yang membeli rumah subsidi tersebut tidak melaksanakan kewajiban membayar cicilannya sesuai dengan waktu yang telah ditentukan, maka yang akan menerima sanksi dari pihak bank adalah debitur tersebut. Kemudian untuk pihak Bank harus selalu melakukan pengawasan secara intensif terkait dengan pemberian kredit, khususnya kredit rumah subsidi, sehingga tidak ada lagi terjadi proses peralihan kredit rumah subsidi sebelum waktunya tanpa pemberitahuan kepada pihak bank dan pihak bank apabila menemukan hal tersebut terjadi, maka harus memberikan sanksi yang tegas bagi pihak yang melakukan hal tersebut. Sedangkan bagi pihak masyarakat yang mengetahui bahwa ada terjadi proses peralihan rumah subsidi sebelum waktunya tanpa sepengetahuan pihak bank, diharapkan untuk melaporkan hal tersebut kepada lembaga yang berwenang (Pihak bank yang memberikan kredit), sehingga nanti dapat diberikan sanksi sesuai dengan ketentuan yang berlaku

\section{DAFTAR PUSTAKA}

\section{Buku/ Jurnal/Artikel:}

Amiruddin \& Asikin, Z. (2018). Pengantar Metode Penelitian Hukum, Cet. 10. Jakarta: PT. Raja Grafindo Persada,

Badrulzaman, M.D. (2014). Aneka Hukum Bisnis. Bandung: Alumni.;

Fuady, M. (2002). Hukum Perkreditan Kontemporer. Bandung: PT. Citra Aditya Bakti.

Fuady, M. (2003). Hukum Kontrak (Dari Sudut Pandang Hukum Bisnis). Bandung: PT Citra Aditya Bakti.

Kaffa, S. (2020). Keabsahan Perjanjian Alih Debitur Kredit Pemilikan Rumah di Bawah Tangan Tanpa Sepengetahuan Pihak Kreditur (Studi Kasus Putusan Nomor 64/Pdt. G/2018/PN. Cbn). Indonesian Notary, 2(3), 626-647

Kusumastuti, D. (2019). Perjanjian Kredit Perbankan Dalam Perspektif Welfare State. Deepublish. 
Mangeswuri, D. R. (2016). Kebijakan Pembiayaan Perumahan Melalui Fasilitas Likuiditas Pembiayaan Perumahan (FLPP). Jurnal Ekonomi \& Kebijakan Publik, 7(1), 83-95.

Putrisani, I. (2018). Analisis Pengalihan Kredit Pemilikan Rumah di Bawah Tangan. Mimbar Keadilan, 14(28).

Rahardjo, A. (2010). Cara Pintar Memilih dan Mengajukan Kredit. Yogyakarta: Pustaka Yustisia.

Sinunga, M..(200o). Manajemen Dana Bank, Edisi Kedua. Jakarta: Bumi Aksara.

Sjahdeini, S.R. (2009). Kebebasan Berkontrak dan Perlindungan yang Seimbang bagi Para Pihak dalam Perjanjian Kredit Bank. Jakarta: Pustaka Utama Grafiti, 158-160

Soegondo. R. (1991). Hukum Pembuktian. Jakarta : PT. Pradnya Paramita

Yusuf, R., \& Maryanto, M. (2018). Peran Notaris Dalam Penggunaan Akta SKMHT Yang Tidak Diikuti APHT Terhadap Debitor Wanprestasi Terkait Pemberian Fasilitas Kredit Pemilikan Rumah Subsidi (Studi Kasus di Bank Tabungan Negara Pekalongan). Jurnal Akta, 5(1), 275-287.

\section{Peraturan Perundang-Undang:}

Indonesia, R. (1945). Undang-Undang Dasar Negara Republik Indonesia

Indonesia, R. Kitab Undang-Undang Hukum Perdata.

Indonesia, R. (1992). Undang-Undang Nomor 4 Tahun 1992 Tentang Perumahan dan Pemukiman.

Indonesia, R. (2016). Peraturan Menteri Pekerjaan Umum Dan Perumahan Rakyat Republik Indonesia Nomor: 21/ PRT /M / 2016 Tentang Kemudahan Dan /Atau Bantuan Perolehan Rumah Bagi Masayarakat Berpenghasilan Rendah.

\section{Website:}

http://pembiayaan.pu.go.id/faq/faq/p/5-apa-yang-dimaksud-dengan-kprbersubsidi,diakses Tanggal 4 Mei 2020.

https://ppdpp.id/profil-p2dpp/, diakses Tanggal 4 Mei 2020. 